\title{
Ending Commercial Lion Farming in South Africa: A Gap Analysis Approach
}

\author{
Jennah Green $^{1}$, Catherine Jakins ${ }^{2}$, Louise de Waal ${ }^{2}$ and Neil D'Cruze ${ }^{1,3, *}$ \\ 1 World Animal Protection 222 Gray's Inn Rd., London WC1X 8HB, UK; \\ JennahGreen@worldanimalprotection.org \\ 2 Blood Lion NPC, P.O. Box 1554, Hermanus 7200, South Africa; info@bloodlions.org (C.J.); \\ management@bloodlions.org (L.d.W.) \\ 3 Recanati-Kaplan Centre, Wildlife Conservation Research Unit, Department of Zoology, University of Oxford, \\ Tubney House, Abingdon Road, Tubney, Abingdon OX13 5QL, UK \\ * Correspondence: NeilDCruze@worldanimalprotection.org
}

check for updates

Citation: Green, J.; Jakins, C.; Waal, L.d.; D'Cruze, N. Ending Commercial Lion Farming in South Africa: A Gap Analysis Approach. Animals 2021, 11, 1717. https://doi.org/10.3390/ ani11061717

Academic Editors: Wayne Boardman and Anne-Lise Chaber

Received: 15 April 2021

Accepted: 5 June 2021

Published: 8 June 2021

Publisher's Note: MDPI stays neutral with regard to jurisdictional claims in published maps and institutional affiliations.

Copyright: (c) 2021 by the authors. Licensee MDPI, Basel, Switzerland. This article is an open access article distributed under the terms and conditions of the Creative Commons Attribution (CC BY) license (https:/ / creativecommons.org/licenses/by/ $4.0 /)$.
Simple Summary: In South Africa, African lions (Panthera leo) are bred on farms for commercial purposes such as tourism, trophy hunting, and the international traditional medicine market. Despite its legal status, South Africa's growing lion farming industry is a contentious issue. In 2020, a high-level panel was appointed to review the policies, legislation, and management of breeding, hunting, trade, and handling of four wildlife species, namely rhino, elephant, leopard, and lions. In May 2021, it was announced that the government will stop issuing permits to new entrants into this industry as well as the issuance of hunting permits and will start amending permit conditions to prohibit breeding and exclude tourism interactions with captive lions, effectively ending the lion farming industry. In order to follow this line of action, a comprehensive, well-managed plan will be required to ensure a responsible transition away from the current industry. Here, using a "gap analysis" management tool, we outline some of the key considerations necessary for a responsible, well-managed exit from the lion farming industry in South Africa. We compiled key background information about the current state of the industry and use this information to identify desired management states and specific steps that could facilitate a successful phase out of lion farming.

Abstract: African lions (Panthera leo) are commercially farmed across South Africa for sport hunting, tourism, and the international bone trade, primarily in Southeast Asia. Despite its legal status, South Africa's growing lion farming industry is a contentious issue. In 2020 a high-level panel was initiated to review the policies, legislation, and management regarding the breeding, hunting, trade, and handling of four wildlife species, including lions. In May 2021, it was announced that the government intends to amend existing permit conditions to prohibit lion breeding and tourism interactions with captive lions, as well as to stop issuing permits to new entrants into the industry, effectively ending lion farming. In order to follow this line of action, a comprehensive, well-managed plan will be necessary to execute a responsible exit from the industry as it currently stands. Using a "gap analysis" management tool, we aim to: (1) outline some of the key considerations regarding the current state of the lion farming industry in South Africa; and (2) propose specific action steps that could be taken within five key areas (regulation, animal welfare, health and safety, equitability, and conservation) to help inform a responsible transition away from this type of wildlife farming in the biodiversity economy. For our gap analysis, we conducted a semi-systematic literature search to compile key background information about the current state of the industry. This information was then used to identify corresponding desired management states, and steps that could facilitate a successful phase out of lion farming in South Africa. We hope our approach helps identify key considerations for a responsible transition and can help aid decisions during the management of this process.

Keywords: African lion; Panthera leo; commercial breeding; wildlife farming; management; gap analysis 


\section{Introduction}

African lions (Panthera leo) are commercially farmed across South Africa. Over the last decade, an industry that began as a handful of small-scale captive breeding operations has grown exponentially to hold a current captive population of up to 8500 lions housed across 300-400 facilities [1,2], contributing an estimated R500 million (US\$42 million) annually to the South African economy [3]. As stated in the Biodiversity Management Plan for African Lions, the primary purpose of these commercial facilities is to breed lions for financial profit [4]. This remit differs distinctly from zoological institutions (that may breed or keep captive lions for conservation), or animal rescue centres and sanctuaries (that house them for protection and rehabilitation purposes) [5].

Commercial lion farming is reported to have emerged in South Africa in response to increasing market demands for lion products [6]. Lions were initially bred in captivity to supply canned hunting operations in the 1990s [7,8]. However, since 2008 they have also been slaughtered for their bones that have been exported in increasing numbers to Southeast Asia for the traditional medicine industry [9]. A significant number of tourismbased industries also benefit from commercial captive lion breeding via non-consumptive purposes. For example, cubs and young adult lions are offered for interactive ecotourism and volunteerism experiences to paying tourists $[1,6,8]$.

Figure 1 illustrates the full list of various known opportunities for commercial use, demonstrating that lions in South Africa can be maintained within one distinct sector (e.g., specifically bred and used solely for canned hunting), or may be traded between sectors at different stages of their development. Specifically, lion cubs can be bred at a single tourist facility where they are maintained for their entire lifespan, or alternatively purchased or rented from specialised breeders and returned once they have outlived their suitability for their tourism function [5]. The extent to which individual lions are traded between these different sectors is currently unclear [8]. However, information obtained through Promotion of Access to Information Act (PAIA) requests indicates that movement of lions between facilities and provinces occurs [10]. A recent survey of 117 captive lion facilities reported that $65 \%$ of facilities examined should be considered 'multi-purpose', with $79 \%$ having engaged with the hunting sector and $66 \%$ having sold skeletons to lion bone traders [6].

Commodity Chain for Lions in South Africa's Commercial Lion Breeding Industry

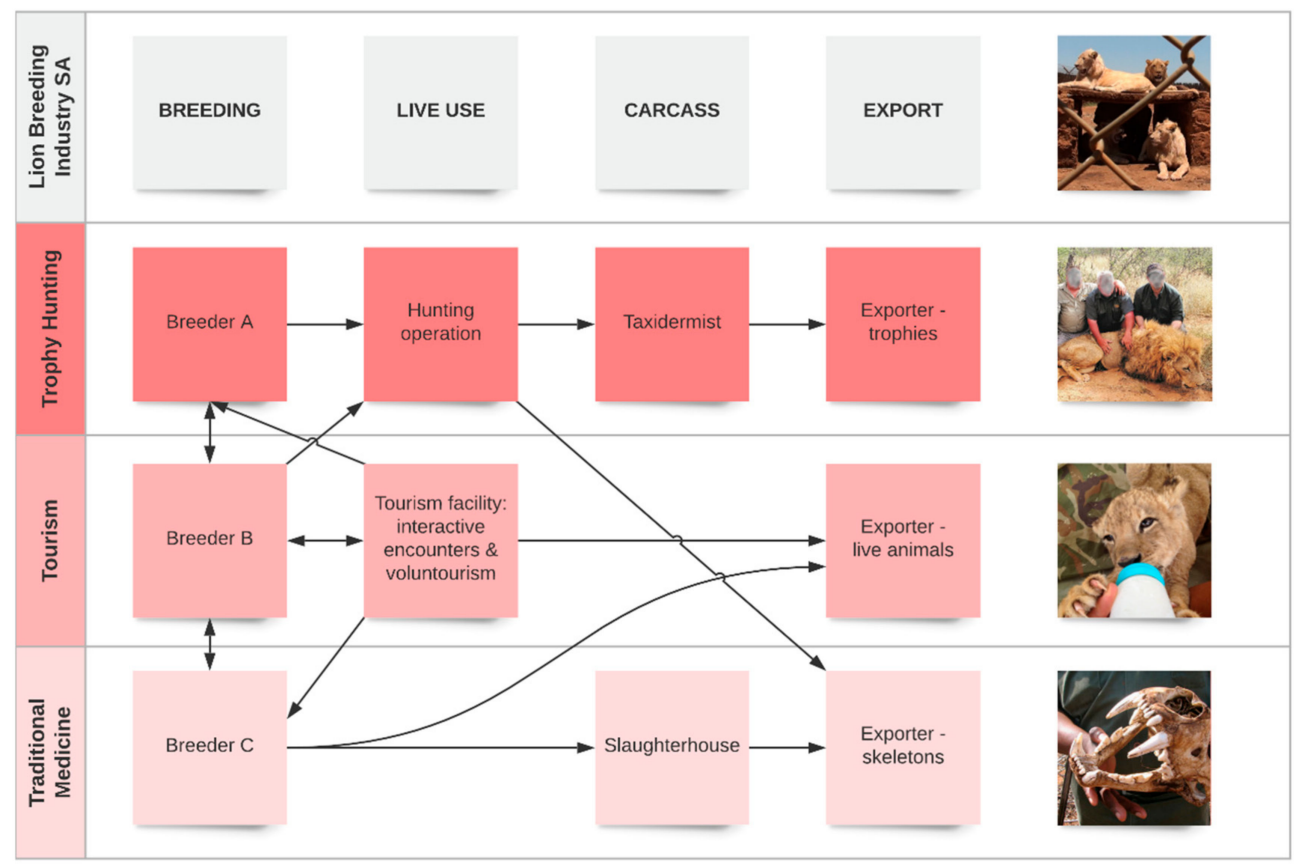

Figure 1. Commodity chain for lions in South Africa's commercial captive breeding industry. The three recognised sectors 
currently involved in the commercial captive breeding of lions are the trophy hunting industry [8], non-consumptive lion tourism and volunteering [11], and international trade of lion bones to Southeast Asia for the traditional medicine industry [9]. This commodity chain highlights the potential for lions to move across sectors in relation to breeding, live use, slaughter and export throughout their lifespan, although the extent to which individual lions are traded between these different sectors is currently unclear [8].

With regards to legislation, lion farming has been permissible in South Africa under a number of different regulations at a national and provincial level [12,13]. Internationally, commercial trade in lions, their body parts, and derivatives are governed by the Convention on International Trade in Endangered Species of Wild Fauna and Flora (CITES) under Appendix B. At the 2016 CITES Conference of the Parties, it was agreed that South Africa would be permitted to export lion bones, provided they are sourced from the captivebred stock, within annual quota limits (established by the South African Department of Forestry, Fisheries, and the Environment (DFFE)), and reported to the CITES Secretariat annually [2,6]. An annual quota of 800 skeletons was established for 2017, which was temporarily increased to 1500 in 2018, but subsequently reduced back to 800 [14], due in part to international criticism. No export quotas were published for 2019 or 2020.

Despite its legal status, South Africa's growing lion farming industry is a contentious issue that has raised animal welfare and conservation conversations among both the scientific community and in wider public discourse [1,12]. Although the impact that farming has on wild lion populations in African range states (currently listed as Vulnerable (IUCN, 2021)) is reported to be minimal [15], its contribution to the conservation of wild lion populations has been questioned [16-18] alongside whether lion farming may be stimulating consumer demand for tiger bone ((Panthera tigris) currently listed as Endangered (IUCN, 2021)) in Southeast Asian markets [9]. In addition, researchers have also raised concerns about the negative impact of lion farming on South Africa's economy through international tourism reputational damage $[3,5]$, and the potential risks of lion farming for animal and public health [19].

Following a decision by the South African High Court in 2019, which determined that the lion skeleton export quotas set in 2017 and 2018 were unlawful and constitutionally invalid [20,21], and potentially spurred by increasing recognition of growing contention towards the industry, the Minister of the DFFE initiated a high-level panel (HLP) to review the policies, legislation, and practises regarding the management, breeding, hunting, and handling of four wildlife species, namely rhino, elephant, leopard, and lions [22]. Following a consultation process, the panel reported their conclusions and recommendations to the Minister in December 2020. The HLP recommendations received Cabinet approval in April 2021 and in May the Minister of DFFE publicly announced her intent to adopt the majority of the HLP recommendations, including to halt and reverse the domestication of lions, an immediate halt on sale of captive lion derivatives, the hunting of captive bred lions and tourism interactions, i.e., effectively ending the commercial captive lion farming industry in South Africa. The recommendations will now go through Parliament with Cabinet approval, although the timeline for this process remains unclear.

Herein, using a "gap analysis" as a management tool (see methods for full description), we aim to: (1) outline some of the key considerations regarding the current state of the lion farming industry in South Africa; and (2) in light of available information propose specific action steps that could be taken within five key areas (regulation, animal welfare, health and safety, equitability, conservation) to help inform a responsible, sustainable, and just transition away from the lion farming industry in South Africa. Although it is not our intention to provide specific solutions or time frames for transition management, we hope that flagging key areas of consideration will help maximise the likelihood of a successful transition and minimise chances of unintended negative impacts. More broadly, we hope that this gap analysis can also serve as a useful case study to aid decision making relating to the commercial captive breeding of other wildlife species elsewhere. 


\section{Materials and Methods}

A gap analysis is a management tool that can be used to compare the current state of an industry with a desired future state, in order to establish the gaps between the two states and identify an appropriate course of action [23]. Gap analyses were first described in the business management literature in the 1980s [24] and have since been adapted for application across a range of different industries [25-27]. They are primarily used in this context for comparison of current performance and desired performance of organisational success or employee output [23]. Although the term 'gap analysis' can also refer to a conservation evaluation technique that identifies areas in which selected elements of biodiversity are underrepresented [28], for the purpose of our study we use gap analysis in the context of industry management (not as a conservation evaluation technique).

For this gap analysis, a semi-systematic literature search was conducted to compile key background information about the current state of the lion farming industry in South Africa. A systematic review of the scientific literature was conducted using an academic database (Web of Science), searching articles for 'Panthera leo' and 'African lion', with the Boolean operator 'AND' and the additional terms 'commercial farming', 'commercial breeding', and 'South Africa'. The literature returned was then used in a 'snowball approach' to identify additional relevant sources (i.e., articles were not returned by the search terms but were cited in papers that were). Some relevant non-scientific literature identified by authors was also considered, namely government reports pertaining to lion farming in South Africa [15,21,22,29], an inspection report from national animal welfare council authority [30], and two media articles [31,32]. These government reports and grey literature were identified through the same 'snowball approach' described for the academic literature search. We also searched the DFFE of South Africa website, using the search term 'lion farming', to identify any reports published between 2015-2020 pertaining to the commercial lion farming industry.

Current management issues identified during this stage of the process were organised into one of five key focus categories: (1) regulation (i.e., adherence to legislation and proper record keeping); (2) animal welfare (i.e., the physical and mental well-being of lions); (3) health and safety (i.e., illnesses, injuries, and biosecurity risks posed to people and lions) (4) equitability (i.e., the financial well-being of people currently dependent on this industry), and (5) conservation (i.e., the survival of wild lions and other species). A team of eight researchers used this information to identify both corresponding desired management states, and specific steps that could facilitate a successful phase out of lion farming in South Africa. The researchers have backgrounds in animal welfare, conservation, and criminal law, and employment experience including the academic, NGO, and communications sectors, with particular expertise focusing on the lion breeding industry in South Africa.

\section{Results}

The systematic search of academic literature provided 31 articles (see Appendix A). An additional 11 articles were identified through the snowball approach (see Appendix B) and a further 7 sources made up of government reports and media articles were identified as being of value to feature in discussions as part of the gap analysis. Following discussions informed by these sources, our gap analysis model summarises the ideal 'desired states' to work towards for effective management of an industry phase out, across five key areas. We identify a number of action steps to aid the process towards a regulated, transparent, and well monitored transition (see Table 1). 
Table 1. Gap analysis table summarising five focus areas for consideration (regulation, animal welfare, health and safety, equitability, and conservation). Based on background literature and discussions with a team of eight researchers, the table also summarises the identified 'current state' (management issues associated with the present industry), the suggested 'desired state' (the perceived ideal management of an industry phase out) and proposed action steps (specific actions that could facilitate the transition between current state and desired state) for each focus area. See Appendix $C$ for a more detailed summary of this gap analysis.

\begin{tabular}{|c|c|c|c|}
\hline Focus Area & $\begin{array}{c}\text { Current State } \\
\text { (Commercial Lion Breeding Ongoing) }\end{array}$ & $\begin{array}{l}\text { Desired State } \\
\text { (Commercial Lion } \\
\text { Breeding Ended) }\end{array}$ & Action Steps \\
\hline Regulation & $\begin{array}{l}\text { Commercial lion breeding in South Africa is } \\
\text { currently governed through a patchwork of } \\
\text { contrasting legislation (across a national, } \\
\text { provincial, and departmental level) and } \\
\text { penalties for infringements of existing } \\
\text { legislation are not always properly enforced. } \\
\text { Baseline data relating to the management of } \\
\text { farms (e.g., lion numbers and studbooks) } \\
\text { appear lacking. } \\
\text { (Current state derived from a number of } \\
\text { records from relevant government reports } \\
\text { [15,21,22] as well as peer-reviewed } \\
\text { publication detailing regulatory processes [5], } \\
\text { and additional publications containing legal } \\
\text { analyses regarding the governing of the lion } \\
\text { farming industry [13,33]). }\end{array}$ & $\begin{array}{l}\text { Commercial lion breeding } \\
\text { facilities are effectively and } \\
\text { transparently monitored } \\
\text { during (and after) a time } \\
\text { bound phase out of the } \\
\text { industry. Penalties for } \\
\text { infringements of the law are } \\
\text { an effective deterrent and are } \\
\text { properly enforced. }\end{array}$ & $\begin{array}{l}\text { New cohesive legislation } \\
\text { (at provincial and } \\
\text { departmental level) is } \\
\text { required to aid the phase } \\
\text { out, in addition to } \\
\text { resources and capacity } \\
\text { provided for the relevant } \\
\text { authorities to enforce new } \\
\text { legislation. Baseline data } \\
\text { detailing lion farm } \\
\text { facilities are kept and } \\
\text { made publicly available. }\end{array}$ \\
\hline Animal Welfare & $\begin{array}{l}\text { Current lion farming practises in South } \\
\text { Africa are having a negative animal welfare } \\
\text { impact for the lion's physical and mental } \\
\text { wellbeing. Additionally, the unregulated } \\
\text { commercial captive breeding of lions in } \\
\text { facilities is resulting in cases of } \\
\text { genetic inbreeding. } \\
\text { (Current state derived from consultation of } \\
\text { an inspection report from the South African } \\
\text { national animal welfare council authority } \\
\text { [30], a court case brought forward to the } \\
\text { High Court in South Africa by the National } \\
\text { Council of the Society for Prevention of } \\
\text { Cruelty to Animals [21] and a peer reviewed } \\
\text { publication returned from our systematic } \\
\text { literature search [8]). }\end{array}$ & $\begin{array}{l}\text { Commercial lion breeding } \\
\text { facilities provide lions the } \\
\text { highest welfare conditions } \\
\text { possible during a time bound } \\
\text { phase out of the industry. } \\
\text { Breeding of new cubs, } \\
\text { slaughter, and direct contact } \\
\text { with lions for commercial } \\
\text { purposes are prohibited } \\
\text { during this time. }\end{array}$ & $\begin{array}{l}\text { The creation of veterinary } \\
\text { protocols to prevent new } \\
\text { lion cub births to underpin } \\
\text { a phase out of the } \\
\text { commercial captive } \\
\text { breeding of lions, as well } \\
\text { as the creation of animal } \\
\text { welfare protocols (e.g., } \\
\text { animal husbandry, health, } \\
\text { enrichment, euthanasia) } \\
\text { which are made publicly } \\
\text { available, to ensure } \\
\text { accountability. }\end{array}$ \\
\hline Health and Safety & $\begin{array}{l}\text { Commercial lion breeding poses a potential } \\
\text { biosecurity risk via disease transfer to } \\
\text { wildlife and people (staff, visitors, and wider } \\
\text { public). Additionally, captive bred lions have } \\
\text { inflicted injuries and mortalities at } \\
\text { commercial facilities and have escaped from } \\
\text { facilities, posing a potential biosecurity and } \\
\text { safety risk. } \\
\text { (Current state derived from consultation of } \\
\text { one peer-reviewed publication detailing the } \\
\text { risk of zoonisis transmission on the farms } \\
\text { [19] as well as recommendations and risk } \\
\text { considerations from the national Tourism } \\
\text { Services Association [34] and media articles } \\
\text { detailing misdemeanors with captive lions } \\
\text { from farms [31,32]). }\end{array}$ & $\begin{array}{l}\text { Commercial lion breeding } \\
\text { facilities provide staff with the } \\
\text { highest health and safety } \\
\text { provisions possible during a } \\
\text { time bound phase out of the } \\
\text { industry. Any disease } \\
\text { outbreaks originating from } \\
\text { lions are effectively detected, } \\
\text { contained, and eradicated } \\
\text { during this time. }\end{array}$ & $\begin{array}{l}\text { Biosecurity, health and } \\
\text { safety and baseline } \\
\text { management protocols } \\
\text { relating to a phase out of } \\
\text { the commercial lion } \\
\text { breeding in RSA are } \\
\text { created and made publicly } \\
\text { available. }\end{array}$ \\
\hline
\end{tabular}


Table 1. Cont.

\begin{tabular}{|c|c|c|c|}
\hline Focus Area & $\begin{array}{c}\text { Current State } \\
\text { (Commercial Lion Breeding Ongoing) }\end{array}$ & $\begin{array}{l}\text { Desired State } \\
\text { (Commercial Lion } \\
\text { Breeding Ended) }\end{array}$ & Action Steps \\
\hline Equitability & $\begin{array}{l}\text { The commercial lion breeding industry is } \\
\text { currently owned by approx. } 400 \text { people } \\
\text { across all known farms, including breeding, } \\
\text { keeping, tourism, and hunting facilities. The } \\
\text { industry employs approximately } 1162 \text { people } \\
\text { across } 4 \text { provinces. } \\
\text { (Current state of equitaibility derived from } \\
\text { consultation of several peer-reviewed } \\
\text { publications detailing the distribution of } \\
\text { finances and employment opportunities } \\
\text { within the sector }[3,5,6] \text { ). }\end{array}$ & $\begin{array}{l}\text { People dependent (directly } \\
\text { and indirectly) on commercial } \\
\text { lion breeding as an important } \\
\text { economic source of income } \\
\text { successfully shift to } \\
\text { alternative sustainable } \\
\text { livelihoods during a time } \\
\text { bound phase out of } \\
\text { the industry. }\end{array}$ & $\begin{array}{l}\text { The creation of sustainable } \\
\text { business transition plans, } \\
\text { sustainable alternative } \\
\text { livelihood protocols, and } \\
\text { sustainable international } \\
\text { donor fundraising plans } \\
\text { (relating to a phase out of } \\
\text { the commercial lion } \\
\text { breeding in RSA), } \\
\text { where required. }\end{array}$ \\
\hline Conservation & $\begin{array}{l}\text { Commercial lion breeding results in animals } \\
\text { that cannot play an active role in wild release } \\
\text { or conservation breeding programmes (e.g., } \\
\text { due to inbreeding and habituation). } \\
\text { Additionally, commercial lion breeding } \\
\text { results in lion body parts and derivatives } \\
\text { that are stockpiled and/or sold to meet } \\
\text { demand for traditional Asian medicine (e.g., } \\
\text { the biggest markets in China and Vietnam). } \\
\text { (Current state derived from consultation of a } \\
\text { number of peer-reviewed publications } \\
\text { describing the impact of farms on wild lion } \\
\text { populations and the relationship between the } \\
\text { industry and the demand for lion bone } \\
\text { exports for traditional Asian medicine } \\
\text { markets }[5,11,11,12,14,17,35-38]) .\end{array}$ & $\begin{array}{l}\text { Commercial lion breeding } \\
\text { facilities do not engage in } \\
\text { activities that have a potential } \\
\text { negative impact on the } \\
\text { conservation of wild lion } \\
\text { populations during (and after) } \\
\text { a time bound phase out of the } \\
\text { industry. The wild release, } \\
\text { sale of live lions or their } \\
\text { derivatives is prohibited } \\
\text { during this time. }\end{array}$ & $\begin{array}{l}\text { Conservation protocols } \\
\text { (i.e., that differentiate } \\
\text { between breeding for } \\
\text { conservation versus } \\
\text { commercial purposes) are } \\
\text { created and made publicly } \\
\text { available, in addition to } \\
\text { management protocols for } \\
\text { the disposal of lion body } \\
\text { parts and other } \\
\text { derivatives, and clear } \\
\text { public messaging } \\
\text { guidance relating to a } \\
\text { phase out of the industry. }\end{array}$ \\
\hline
\end{tabular}

\subsection{Regulation}

In its current state, the lion farming industry is governed by a patchwork of contrasting legislation (pertaining to captive lion breeding, trading, hunting, and keeping) across multiple provincial and national authorities, with disparities that leave legal loopholes which create opportunity for harmful and fraudulent activity [33]. For example, lion euthanasia is prohibited in the North West province, but lions that are not sold for breeding or hunting can be translocated to the neighbouring Free State province where euthanasia is permitted [6]. Similarly, minimum release times for captive hunts, i.e., the release time between a captive bred lion set free onto hunting farm and the actual hunt, varies across provinces. For example, North West province has the shortest release time of 96 hours and as a result many lions are transported to this province for captive hunts [10].

There is also a paucity of publicly available information concerning the scope and scale of the captive lion industry, presumably because a complete national audit has never been undertaken [5]. The absence of transparent and centralised baseline information (such as studbooks, veterinary records, lion farm registers, employment records, and other financial data), and the issuing authority for permits existing at the provincial level with no overarching national level oversight or record keeping, impedes the ability of relevant authorities to manage the industry and ensure that it is compliant with existing legislation [33]. For example, it is more challenging for South Africa to comply with annual CITES quotas given that the total number of skeletons produced by each province is not being properly documented $[10,20]$.

Consequently, to help reach its desired state, we surmised that the lion farming industry would benefit from being effectively and transparently monitored during (and after) a time bound phase out of the industry, and that properly enforced penalties for any 
infringements of the law would be required to act as an effective deterrent. In terms of specific action steps, we identified that the creation and communication of new cohesive legislation (at provincial and national level), the collection of publicly available baseline data, a national database of pre-existing permits pertaining to this industry and the provision of training and funds to enforcement agencies represent priority areas that require particular consideration. These suggestions are reflective of the recommendations outlined in the high-level panel review report [29].

\subsection{Animal Welfare}

Animal welfare concerns associated with the lion farming industry have been well documented over recent years. In particular, facility inspections conducted by South Africa's National Council of Societies for the Prevention of Cruelty to Animals (NSPCA) found substandard conditions including inadequate hygiene, insufficient diet, and a lack of necessary provisions at nearly half of the 95 lion farms inspected [30]. Other reported concerns include "speed breeding" practises whereby breeders remove young cubs from lionesses before they are weaned, to force a premature return to oestrus for faster breeding cycles, which can take a toll on the physical and mental wellbeing of both lioness and cub [8]. In addition, concerns resulting from high inbreeding and other poorly managed breeding (which can result in reduced genetic variation, low reproductive performance, increased cub mortality, and reduced immune competence) have been raised [8].

To achieve their desired management state, as a result of this gap analysis we concluded that lion farms should be required to provide lions the highest welfare conditions possible, whilst prohibiting any breeding of new cubs, slaughter or hunting of lions, and direct human contact with lions for commercial purposes, during a time bound phase out of the industry. To achieve this, we identified the need for trained veterinary professionals to ensure the prevention of new captive born cubs via appropriate methods (e.g., contraception, sterilization, or separate sex housing), the registration of all lions at captive commercial facilities on a centralised national database (for example via a robust and informed microchipping programme), and the benefits of making all animal welfare protocols pertaining to animal husbandry, health, enrichment, and euthanasia publicly available during the phase out of the lion farming industry.

\subsection{Health and Safety}

The lion farming industry poses an on-going biosecurity risk via potential disease transfer to staff, visitors, and the wider public [19]. More than 60 pathogenic organisms have been identified in African lions, among which are several species that can be transmitted from lions to other species, including humans [19]. Lion farms are likely to pose risks of zoonotic pathogen transmission to the public because a key part of the industry is ecotourism, where tourists have direct contact with lions on a regular basis-in some cases without basic hygiene protocols (e.g., hand sanitizing) [19]. Lion farms also pose a safety risk to workers (e.g., farm workers, slaughterhouse staff, and taxidermists), visitors, and local communities. Specifically, captive bred lions have inflicted injuries and mortalities at lion farms offering interactive experiences with direct animal contact [31] and incidents have also been reported of lions escaping their enclosures and running stray in the local area [32].

To help transition away from this current situation to its desired state, we surmised that appropriate biosecurity, health and safety, and management protocols should be established for the lion farming industry and made publicly available during a time bound phase out. With regards to specific action steps, we identified that measures such as the provision of appropriate personal protective equipment (PPE), upkeep of enclosure maintenance, protocols pertaining to animal husbandry, and responses to any outbreaks of zoonotic disease would also help safeguard animals and people working within the industry (and the wider public) during this time. As a further precautionary measure, we also identified that any facilities remaining open to tourists during the phase out period 
should operate on an observation-only basis to minimize the risk of zoonotic disease transmission and predator attacks.

\subsection{Equitability}

Lion farming is often described as a substantial contributor to job creation in the South African economy that provides a valuable source of income for hundreds of South Africans (most of whom are thought to be concentrated in the North West and Free State provinces) $[3,5,6]$. However, there are concerns that in the long-term, the lion farming industry may have a "net negative" impact on the South African economy. For example, one study quantified reputational damage to South Africa from supporting captive predator breeding at $\$ 2.79$ billion in Net Present Value Terms (NPV) over a ten-year period [5]. In addition, the use of volunteer programmes (that feed revenue and free labour into some lion farms) has been criticised for depriving the local labour force of employment opportunities [5].

To help transition away from this current situation to its desired state, we surmised that individuals who are economically reliant (directly and indirectly) on lion farming should successfully shift to sustainable alternative forms of income generation during a time bound phase out of the industry. To aid this transition we identified sustainable business transition plans (for lion farm owners) and sustainable alternative livelihood protocols (for lion farm employees) should be created, potentially with assistance from the governmental, private, and NGO sectors where required. Given the likely gradual nature of an industry phase out, relevant training and support could be provided (for example, through the Sector Education and Training Authority (SETA), a vocational skills training organisation in South Africa), to relevant employees while the current generation of captive bred lions remain housed at lion farms to ensure employment viability in alternative sectors.

\subsection{Conservation}

Currently, captive-bred (including farmed) lions do not play any role in conservation breeding or wild release programmes, due in part to habituation with people, as well as genetic unsuitability from inbreeding and crossbreeding risking the introduction of genetic pollution to wild populations [11]. Despite this fact, the conservation impacts of the lion farming industry can be overplayed in this regard (Moorhouse et al., submitted). For example, some volunteer tourists pay to participate in 'husbandry' at commercial facilities under the marketing pretext that they are contributing towards predator rehabilitation and future release back into the wild [5].

There is also concern that the lion farming industry could be contributing to pressure on wild big cat populations. Specifically, although direct links between legal trade in farmed lion parts and the targeted poaching of wild lion populations in South Africa (and other range states) has yet to be evidenced [12], there is reasonable concern the situation could arise $[29,35]$. Moreover, given that tiger bone wine is consumed amongst urban public in China and Vietnam [14], and that lion bone is variously used as a substitute [36], concerns that the lion farming industry in South Africa could negatively impact wild tiger populations through demand stimulation should be considered [14].

Consequently, to help reach its desired state, we concluded that lion farms should not engage in activities that have could potentially have a negative impact on wild lion populations in South Africa and elsewhere during a time bound phase out. To achieve this, we identified the need for management protocols and public messaging guidance (to support efforts that would prohibit the release of lions in to the wild, the sale of farmed live lions, and the sale/stockpile of their derivatives), and the benefit of increasing enforcement capacity during this time (in anticipation of a similar situation to the South African rhino horn trade, whereby increased restrictions were initially contested by market participants, resulting in illegal wildlife trade activity) [6,39]. 


\section{Discussion}

Although the South African lion farming industry has burgeoned in recent decades, during the last five years there have also been several key developments that are likely to have limited several major components of its revenue stream. Noteworthy (but not exhaustive) in this regard is the USA's suspension on imports of captive-bred lion trophies in 2016 [6], Safari Club International's adoption of a policy stance opposing the hunting of captive-bred lions [40], the Southern Africa Tourism Services Association's categorization of tactile interactions with all infant wild animals, canned hunting, and breeding of lions as unacceptable (as per its animal interaction guidelines [34]), the South African High Court ruling in 2019 that determined the annual lion bone quota was unlawful and constitutionally invalid [21], the reduced tourist and trophy hunter numbers as a result of the COVID-19 global pandemic [41], and Vietnam's ban on imports of all wildlife derivatives also following the COVID-19 pandemic [42].

The decision made by the Minister of DFFE as a result of the high-level panel recommendations represents a critical moment in the on-going discourse surrounding this controversial commercial enterprise. Following the recommendations to end commercial lion farming in South Africa, a comprehensive and well-managed plan will be required to facilitate a responsible exit from the industry. To that end, this gap analysis summarises some of the management issues, their corresponding ideal 'desired states', and identifies a number of action steps to aid the process towards a regulated, transparent and well-monitored time bound transition that mitigates potential unintended negative consequences for the lions and people currently operating within the industry.

Given that the current management issues identified through this gap analysis ranged across diverse and complex areas (i.e., regulation, animal welfare, conservation, health and safety, and equitability), it is logical to assume that a wide range of specialised stakeholders will be required to successfully develop and implement an effective and responsible transition away from lion farming in South Africa. Consequently, we recommend the creation of a robust, collaborative process with open forums for addressing issues through information sharing and consensus-based decision-making (e.g., see [43]). Many specialised frameworks have been developed to address such multi-faceted processes [44]. Stakeholder analysis can identify the perceptions and roles of different actors and identify underlying inter-stakeholder conflicts whereas scenario techniques can provide a powerful tool to explore potential trade-offs between different stakeholder views [44]. Pre-emptive resolution of potential conflict between stakeholders can reduce overall costs for stakeholders and governments during the management process [44]. We also note that, especially in light of competing values, such a process may also benefit from being led by a non-advocacy and non-litigious body to earn the trust and support of everyone representing a diversity of values [43].

Once these types of forums have been established, a logical next step in the process would be the early development of a change management roadmap as a method to help systematically plan, assign personal or institutional accountability for, and facilitate effective communication throughout, an effective time bound strategy for industrial change. In particular, it has been posited that these types of wildlife management plans can benefit from the application of logic models (a management tool that identifies a list of actions to be taken with specific achievable outputs as a tool for organising information in an if-then sequence (see [45])). Likewise, the use of graphical management plans could add value by providing a strategic framework (with clear vision, goals, objectives, actions, outcomes, and outputs for practical decision making [45] to identify specific pathways to industry transition). To help maximise chances of success, efforts to reduce consumer demand for lion products should be based on human behaviour change concepts that adhere to theories of best practice [46]. Although it is not our intention to provide specific solutions or time frames for transition management, we hope that flagging key areas of consideration will help to maximise the likelihood of a successful transition and minimise chances of unintended negative impacts. 
It is important to note that lions are just one of the many wild animal species that are captive bred for commercial purposes in South Africa [47]. Moreover, trade of captivesourced wildlife and wildlife 'products' has become increasingly more common in recent decades across most taxa [48]. Possible reasons for the increased trade of captive-sourced wildlife include perceived reliability, quality assurance, public perception regarding exploitation of wild animals, controls on wild harvest, or declining availability of wild animals [48]. However, concerns have been raised, given that some captive-bred wild species stocks may impact negatively on wild populations [47], involve poor animal welfare conditions [49], and/or biosecurity risks [50] that are deemed untenable.

In light of the potential negative impacts associated with wildlife farming, formal policies to end the commercial captive breeding for certain wildlife species have been adopted in a number of different countries in recent decades. Notable examples include the decision to stop mink fur farming in the UK [51], to shift away from sea turtle meat farming on Réunion Island [52], and to close bear farms across South Korea and Vietnam [53,54]. More recently, in China there have been reports by state-run media outlets that an estimated 19,000 wildlife farms may have been shut down around the country following COVID-19 related concerns [55]. Given the possibility of similar decision-making in the future, we draw attention to the potential for this type of approach to be applied to other scenarios where a transition away from the commercial captive breeding of wildlife species is being considered and alternative solutions adopted.

In some scenarios, wildlife farms have made a successful transition away from commercial captive breeding and have instead focused on providing lifetime care for injured and/or confiscated wildlife. For example, Kélonia: Observatory of Marine Turtles (formerly a facility where personnel collected between 5000 and 20,000 wild green turtle hatchlings annually and raised them to marketable size) was transformed into a sea turtle research, education and rescue centre as a result of funding provided by The European Union and Regional Council [52]. Similar alternative facilities for lions potentially already exist within South Africa (e.g., between 11\% and 13\% of facilities surveyed in 2018 considered one of their purposes to be that of a sanctuary or rehabilitation centre for lions [6]) and could provide a useful starting point from which to expand a managed transition away from commercial operations. However, the extent to which this is feasible and/or manageable is not currently clear and requires further investigation.

Despite the potential benefits that a gap analysis can bring to wildlife management planning decisions, we acknowledge that there are some limitations associated with our approach. In particular, this gap analysis was carried out by a relatively small number of researchers, with experience and expertise gained via employment limited to the academic, $\mathrm{NGO}$, and communications sectors, and was not based on a full systematic review of the current literature pertaining to the lion farming industry in South Africa. As such, it is possible that this analysis did not capture all of the management issues that would require consideration as part of an effective and responsible phase out. Despite this, we believe that this gap analysis provides a comprehensive, timely, and useful starting point that can be used alongside the recommendations of the high-level panel report to guide transition planning to end the lion farming industry in South Africa.

\section{Conclusions}

Lion farming in South Africa currently takes place against the backdrop of a controversial multifaceted debate [14]. There is no doubt the transition away from commercial captive lion breeding in South Africa will present significant change management challenges and great caution will be required to avoid unintended negative consequences for both lions and people. However, we posit that these challenges are not insurmountable and untenable negative impacts are by no means inevitable. In this regard, we suggest that the application of a gap analysis could be an effective tool as part of a wider change management approach (not only for the lion industry in South Africa, but for other wildlife farming scenarios involving other species elsewhere also). 
Author Contributions: Conceptualization, N.D. and L.d.W.; methodology, N.D.; investigation and analysis, N.D., L.d.W., J.G. and C.J.; writing-original draft preparation, J.G. and N.D.; writingreview and editing, J.G., N.D., C.J. and L.d.W. All authors have read and agreed to the published version of the manuscript.

Funding: This research received no external funding.

Institutional Review Board Statement: Not applicable.

Informed Consent Statement: Not applicable.

Data Availability Statement: Not applicable.

Acknowledgments: The authors would like to thank Eyob Asfaw, Edith Kabesiime, Patrick Muinde, Gilbert Sape, Ruth De Vere and Stephanie Klarmann for their valuable contributions to discussions during development of the gap analysis.

Conflicts of Interest: The authors declare no conflict of interest.

\section{Appendix A. Literature Returned from the Systematic Search for Peer-Reviewed Articles on an Academic Database (Web of Science)}

Bertschinger, H.J. and Caldwell, P., 2016. Fertility suppression of some wildlife species in southern Africa-A review. Reproduction in Domestic Animals, 51, pp. 18-24.

Buk, K.G., van der Merwe, V.C., Marnewick, K. and Funston, P.J., 2018. Conservation of severely fragmented populations: lessons from the transformation of uncoordinated reintroductions of cheetahs (Acinonyx jubatus) into a managed metapopulation with self-sustained growth. Biodiversity and conservation, 27(13), pp. 3393-3423.

Callealta, I., Ganswindt, A., Malan, M. and Lueders, I., 2019. Non-surgical artificial insemination using a GnRH analogue for ovulation induction during natural oestrus in African lions (Panthera leo). Theriogenology, 139, pp. 28-35.

Caro, T. and Riggio, J., 2014. Conservation and behavior of Africa's "Big Five". Current Zoology, 60(4), pp. 486-499.

Coals, P., Dickman, A., Hunt, J., Grau, A., Mandisodza-Chikerema, R., Ikanda, D., Macdonald, D.W. and Loveridge, A., 2020. Commercially-driven lion part removal: What is the evidence from mortality records? Global Ecology and Conservation, 24, p. e01327.

Cox, T.E., Murray, P.J., Hall, G.P. and Li, X., 2012. Manipulating resource use by goats with predator fecal odors. Wildlife Society Bulletin, 36(4), pp. 802-806.

Davies-Mostert, H.T., Mills, M.G. and Macdonald, D.W., 2015. The demography and dynamics of an expanding, managed African wild dog metapopulation. African Journal of Wildlife Research, 45(2), pp. 258-273.

Durrheim, D.N. and Leggat, P.A., 1999. Risk to tourists posed by wild mammals in South Africa. Journal of Travel Medicine, 6(3), pp. 172-179.

Fletcher-Barnes, E., 2020. Cuddle, kill, conserve: A posthuman analysis of the African lion within the South African wildlife security assemblage. International Journal of Sociology and Social Policy.

Green, J., Jakins, C., Asfaw, E., Bruschi, N., Parker, A., de Waal, L. and D'Cruze, N., 2020. African Lions and Zoonotic Diseases: Implications for Commercial Lion Farms in South Africa. Animals, 10(9), p. 1692.

Harris, L.A., Steinetz, B.G., Bond, J.B., Lasano, S. and Swanson, W.F., 2008. Refinement of a commercial bench-top relaxin assay for pregnancy diagnosis using urine from domestic and nondomestic felids. Journal of Zoo and Wildlife Medicine, 39(2), pp. 170-179.

Hay, C.T., Cross, P.C. and Funston, P.J., 2008. Trade-offs of predation and foraging explain sexual segregation in African buffalo. Journal of Animal Ecology, 77(5), pp. 850-858.

Herz, V. and Kirberger, R.M., 2004. Nutritional secondary hyperparathyroidism in a white lion cub (Panthera leo), with concomitant radiographic double cortical line: clinical communication. Journal of the South African Veterinary Association, 75(1), pp. 49-53. 
Hunter, L.T., White, P., Henschel, P., Frank, L., Burton, C., Loveridge, A., Balme, G., Breitenmoser, C. and Breitenmoser, U., 2013. Walking with lions: why there is no role for captive-origin lions Panthera leo in species restoration. Oryx, 47(1), pp. 19-24.

Hutchinson, A. and Roberts, D.L., 2020. Differentiating captive and wild African lion (Panthera leo) populations in South Africa, using stable carbon and nitrogen isotope analysis. Biodiversity and Conservation, 29(7), pp. 2255-2273.

Kurt, T., Altungag, Y. and Özsoy, S., 2020. Treatment of Pathological Fractures in Two Lion Cubs (Panthera leo) with Nutritional Secondary Hyperparathyroidsm. Kafkas Üniversitesi Veteriner Fakültesi Dergisi, 26(6), pp. 817-821.

Lane, E.P., Brettschneider, H., Oosthuizen, A., Dalton, D.L., Kotze, A., Caldwell, P., Du Plessis, L. and Steyl, J., 2016. Feline panleukopaenia virus in captive non-domestic felids in South Africa. Onderstepoort Journal of Veterinary Research, 83(1), pp. 1-8.

Lindsey, P., Alexander, R., Balme, G., Midlane, N. and Craig, J., 2012. Possible relationships between the South African captive-bred lion hunting industry and the hunting and conservation of lions elsewhere in Africa. African Journal of Wildlife Research, 42(1), pp. 11-22.

Lueders, I., Ludwig, C., Schroeder, M., Mueller, K., Zahmel, J. and Dehnhard, M., 2014. Successful nonsurgical artificial insemination and hormonal monitoring in an Asiatic golden cat (Catopuma temmincki). Journal of Zoo and Wildlife Medicine, 45(2), pp. 372-379.

Miller, S.M., Funston, P.J. and Tambling, C.J., 2015. GrowLS: lion (Panthera leo) population growth simulation for small reserve management planning. African Journal of Wildlife Research, 45(2), pp. 169-177.

Morar, D., Tijhaar, E., Negrea, A., Hendriks, J., Van Haarlem, D., Godfroid, J., Michel, A.L. and Rutten, V.P.M.G., 2007. Cloning, sequencing and expression of white rhinoceros (Ceratotherium simum) interferon-gamma (IFN- $\gamma$ ) and the production of rhinoceros IFN- $\gamma$ specific antibodies. Veterinary immunology and immunopathology, 115(1-2), pp. 146-154.

Mossaz, A., Buckley, R.C. and Castley, J.G., 2015. Ecotourism contributions to conservation of African big cats. Journal for Nature Conservation, 28, pp. 112-118.

O'Kane, C.A. and Macdonald, D.W., 2016. An experimental demonstration that predation influences antelope sex ratios and resource-associated mortality. Basic and Applied Ecology, 17(4), pp. 370-376.

Pirie, T.J., Thomas, R.L. and Fellowes, M.D., 2017. Game fence presence and permeability influences the local movement and distribution of South African mammals. African Zoology, 52(4), pp. 217-227.

Romanach, S.S., Lindsey, P.A. and Woodroffe, R., 2007. Determinants of attitudes towards predators in central Kenya and suggestions for increasing tolerance in livestock dominated landscapes. Oryx, 41(2), pp. 185-195.

Scheiss-meier, M.O.N.I.K.A., Ramsauer, S., Gabanapelo, T. and König, B., 2007. Livestock predation-insights from problem animal control registers in Botswana. The Journal of Wildlife Management, 71(4), pp. 1267-1274.

Seoraj-Pillai, N. and Pillay, N., 2017. A meta-analysis of human-wildlife conflict: South African and global perspectives. Sustainability, 9(1), p. 34.

Tambling, C.J., Druce, D.J., Hayward, M.W., Castley, J.G., Adendorff, J. and Kerley, G.I., 2012. Spatial and temporal changes in group dynamics and range use enable anti-predator responses in African buffalo. Ecology, 93(6), pp. 1297-1304.

Van Dyk, G. and Slotow, R., 2003. The effects of fences and lions on the ecology of African wild dogs reintroduced to Pilanesberg National Park, South Africa. African Zoology, 38(1), pp. 79-94.

Williams, V.L. and 't Sas-Rolfes, M.J., 2019. Born captive: A survey of the lion breeding, keeping and hunting industries in South Africa. PLoS ONE, 14(5), p. e0217409.

Williams, V.L., Loveridge, A.J., Newton, D.J. and Macdonald, D.W., 2017. A roaring trade? The legal trade in Panthera leo bones from Africa to East-Southeast Asia. PLoS ONE, 12(10), p. e0185996. 


\section{Appendix B. Additional Relevant Literature Identified through a Snowball Approach from the Initial Systematic Search}

Coals, P.; Burnham, D.; Loveridge, A.; Macdonald, D.W.; Sas-Rolfes, M. 't; Williams, V.L.; Vucetich, J.A. The Ethics of Human-Animal Relationships and Public Discourse: A Case Study of Lions Bred for Their Bones. Animals 2019, 9, 52, doi:10.3390/ani9020052.

Harvey, R.G. Towards a Cost-Benefit Analysis of South Africa's Captive Predator Breeding Industry. Global Ecology and Conservation 2020, 23, e01157.

Schroeder, R.A. Moving Targets: The 'Canned' Hunting of Captive-Bred Lions in South Africa. African Studies Review 2018, 61, 8-32.

Coals, P.; Moorhouse, T.P.; D'Cruze, N.C.; Macdonald, D.W.; Loveridge, A.J. Preferences for Lion and Tiger Bone Wines amongst the Urban Public in China and Vietnam. Journal for Nature Conservation 2020, 57, 125874.

Bauer, H.; Nowell, K.; Sillero-Zubiri, C.; Macdonald, D.W. Lions in the Modern Arena of CITES. Conservation Letters 2018, 11, e12444.

Hinsley, A. Lion and Tiger Farming May Be Inhumane, but We Don't Know If It Increases Poaching. The Conversation 2019.

Williams, V.L.; Loveridge, A.J.; Newton, D.J.; Macdonald, D.W. Questionnaire Survey of the Pan-African Trade in Lion Body Parts. PLoS ONE 2017, 12, e0187060.

Van der Merwe, P.; Saayman, M.; Els, J.; Saayman, A. The Economic Significance of Lion Breeding Operations in the South African Wildlife Industry. International journal of biodiversity and conservation 2017, 9, 314-322.

Coals, P.; Burnham, D.; Johnson, P.J.; Loveridge, A.; Macdonald, D.W.; Williams, V.L.; Vucetich, J.A. Deep Uncertainty, Public Reason, the Conservation of Biodiversity and the Regulation of Markets for Lion Skeletons. Sustainability 2019, 11, 5085.

Wilson, A. Animal Law in South Africa: "Until the Lions Have Their Own Lawyers, the Law Will Continue to Protect the Hunter; dA.Derecho Animal (Forum of Animal Law Studies), 2019.

Everatt, K.T.; Kokes, R.; Pereira, C.L. Evidence of a Further Emerging Threat to Lion Conservation; Targeted Poaching for Body Parts. Biodiversity and Conservation 2019, 28, 4099-4114.

\section{Appendix C.}

Table A1. Detailed summary of results Table 1.

\begin{tabular}{|c|c|c|c|}
\hline Focus & $\begin{array}{c}\text { Current State } \\
\text { (Commercial Lion Breeding } \\
\text { Ongoing) }\end{array}$ & $\begin{array}{l}\text { Desired State } \\
\text { (Commercial Lion } \\
\text { Breeding Ended) }\end{array}$ & Action Steps \\
\hline \multirow{3}{*}{$\begin{array}{c}\text { Regulation } \\
\text { To identify the current } \\
\text { state of regulatory } \\
\text { practises for lion farming } \\
\text { in South Africa, we } \\
\text { consulted a number of } \\
\text { records from relevant } \\
\text { government reports } \\
\text { [15,21,22] as well as } \\
\text { peer-reviewed publication } \\
\text { detailing regulatory } \\
\text { processes [5], and } \\
\text { additional publications } \\
\text { containing legal analyses } \\
\text { regarding the governing of } \\
\text { the lion farming industry } \\
\text { [13,33] }\end{array}$} & $\begin{array}{l}\text { 1.1 A patchwork of contrasting } \\
\text { legislation (across a national, } \\
\text { provincial, and departmental } \\
\text { level) applies to the commercial } \\
\text { lion breeding in RSA. }\end{array}$ & \multirow{3}{*}{$\begin{array}{l}\text { Commercial lion breeding } \\
\text { facilities are effectively } \\
\text { and transparently } \\
\text { monitored during (and } \\
\text { after) a time bound phase } \\
\text { out of the industry. } \\
\text { Penalties for } \\
\text { infringements of the law } \\
\text { are an effective deterrent } \\
\text { and are properly enforced. }\end{array}$} & $\begin{array}{l}\text { 1.1 New cohesive legislation (at } \\
\text { provincial and departmental level) } \\
\text { created to aid the phase out and } \\
\text { then prohibit commercial lion } \\
\text { breeding in RSA. }\end{array}$ \\
\hline & $\begin{array}{l}\text { 1.2 The penalties for major } \\
\text { infringements of the existing } \\
\text { legislation (e.g., CITES, Animal } \\
\text { Welfare) regulating commercial } \\
\text { lion breeding in RSA are not } \\
\text { always properly enforced. }\end{array}$ & & $\begin{array}{l}\text { 1.2 Relevant authorities provided } \\
\text { with resources and capacity to } \\
\text { enforce infringements of new } \\
\text { cohesive legislation (facilitating } \\
\text { phase out and subsequent } \\
\text { prohibition of commercial lion } \\
\text { breeding in RSA). }\end{array}$ \\
\hline & $\begin{array}{l}\text { 1.3 Baseline data (e.g., lion } \\
\text { numbers, registered farms, } \\
\text { studbooks, veterinary records, } \\
\text { employment/economics) } \\
\text { relating to commercial lion } \\
\text { breeding appears lacking and is } \\
\text { not publicly available. }\end{array}$ & & $\begin{array}{l}\text { 1.3 Baseline data (e.g., lion numbers, } \\
\text { registered farms, studbooks, } \\
\text { veterinary records, } \\
\text { employment/economics) required } \\
\text { to monitor the phase out of } \\
\text { commercial lion breeding in RSA) is } \\
\text { kept and made publicly available. }\end{array}$ \\
\hline
\end{tabular}


Table A1. Cont.

Focus Area

Animal Welfare
To summarise the current
state of animal welfare on
lion farms we consulted
an inspection report from
the South African national
animal welfare council
authority [30], a court case
brought forward to the
High Court in South
Africa by the National
Council of the Society for
Prevention of Cruelty to
Animals [21] and a peer
reviewed publication
returned from our
systematic literature
search [8].

Health and Safety

To summarise the current state of health and safety on lion farms in South

Africa we consulted one peer-reviewed publication detailing the risk of zoonisis transmission on the farms [19] as well as recommendations and risk considerations from the national Tourism Services Association [34] and media articles detailing misdemeanors with captive lions from farms [31,32]

Equitability
To summarise the current
state of equitabality within
the lion farm industry we
consulted several
peer-reviewed
publications detailing the
distribution of finances
and employment
opportunities within the
sector $[3,5,6]$

4.1 The commercial lion breeding industry is currently owned by approx. 400 people across all known farms, including breeding, keeping, tourism and hunting facilities.

4.2 The commercial lion breeding industry directly employs approx. 549 people across all known facilities and an additional 613 people indirectly across 4 provinces.

4.3 Commercial lion breeding industry recruits international volunteers who pay facilities to gain experience of working with captive lions.

\section{Desired State \\ (Commercial Lion \\ Breeding Ended)}

Commercial lion breeding facilities provide lions the highest welfare conditions possible during a time bound phase out of the industry. Breeding of new cubs, slaughter, and direct contact with lions for commercial purposes are prohibited during this time.

2.3 Commercial lion breeding is welfare impact relating the physical domain (e.g., genetic disorders, morbidity).

3.1 Commercial lion breeding risk via disease transfer to 3.2 Captive bred lions have inflicted injuries and mortalities facilities in RSA.

3.3 Captive bred lions have escaped from commercial breeding facilities in RSA and safety risk.

Commercial lion breeding facilities provide staff with the highest health and safety provisions possible during a time bound

phase out of the industry. Any disease outbreaks originating from lions are effectively detected, contained, and eradicated during this time.

People dependent (directly and indirectly) on commercial lion breeding as an important economic source of income successfully shift to alternative sustainable livelihoods during a time bound phase out of the industry.
2.1 Veterinary protocols to prevent new lion cub births to underpin a phase out of the commercial captive breeding of lions.

2.2 Animal welfare protocols focused on the mental domain (e.g., animal husbandry, health, enrichment, euthanasia) relating to a phase out of the commercial lion breeding in RSA) are created and made publicly available.

2.3 Animal welfare protocols focused on the physical domain (e.g., animal husbandry, health, enrichment, euthanasia) relating to a phase out of the commercial lion breeding in RSA) are created and made publicly available.

\subsection{Biosecurity protocols relating to} a phase out of the commercial lion breeding in RSA) are created and made publicly available.

3.2 Health and safety protocols relating to a phase out of the commercial lion breeding in RSA) are created and made publicly available.

3.3 Baseline management protocols (e.g., enclosure maintenance) relating to a phase out of the commercial lion breeding in RSA) are created and made publicly available.

4.1 Sustainable business transition plans (relating to a phase out of the commercial lion breeding in RSA) are created where required.

4.2 Sustainable alternative livelihood protocols (relating to a phase out of the commercial lion breeding in RSA) are created where required.

4.3 Sustainable international donor fundraising plans (relating to a phase out of the commercial lion breeding in RSA) are created where required. 
Table A1. Cont.

\begin{tabular}{|c|c|c|c|}
\hline Focus Area & $\begin{array}{c}\text { Current State } \\
\text { (Commercial Lion Breeding } \\
\text { Ongoing) }\end{array}$ & $\begin{array}{l}\text { Desired State } \\
\text { (Commercial Lion } \\
\text { Breeding Ended) }\end{array}$ & Action Steps \\
\hline \multirow{3}{*}{$\begin{array}{c}\text { Conservation } \\
\text { To summarise the current } \\
\text { impact of lion farming on } \\
\text { conservation we consulted } \\
\text { a number of } \\
\text { peer-reviewed } \\
\text { publications describing } \\
\text { the impact of farms on } \\
\text { wild lion populations and } \\
\text { the relationship between } \\
\text { the industry and the } \\
\text { demand for lion bone } \\
\text { exports for traditional } \\
\text { Asian medicine markets } \\
\text { [5,11,11,12,14,17,35-38] }\end{array}$} & $\begin{array}{l}5.1 \text { Commercial lion breeding } \\
\text { results in animals that cannot } \\
\text { play an active role in wild } \\
\text { release or conservation breeding } \\
\text { programmes (e.g., due to } \\
\text { inbreeding and habituation). }\end{array}$ & \multirow{3}{*}{$\begin{array}{l}\text { Commercial lion breeding } \\
\text { facilities do not engage in } \\
\text { activities that have a } \\
\text { potential negative impact } \\
\text { on the conservation of } \\
\text { wild lion populations } \\
\text { during (and after) a time } \\
\text { bound phase out of the } \\
\text { industry. The wild release, } \\
\text { sale of live lions or their } \\
\text { derivatives is prohibited } \\
\text { during this time. }\end{array}$} & $\begin{array}{l}\text { 5.1 Conservation protocols (i.e., that } \\
\text { differentiate between breeding for } \\
\text { conservation versus commercial } \\
\text { purposes) are created and made } \\
\text { publicly available. }\end{array}$ \\
\hline & $\begin{array}{l}5.2 \text { Commercial lion breeding } \\
\text { results in lion body parts and } \\
\text { derivatives that are stockpiled } \\
\text { and/or sold to meet demand for } \\
\text { traditional Asian medicine (e.g., } \\
\text { the biggest markets in China } \\
\text { and Vietnam). }\end{array}$ & & $\begin{array}{l}\text { 5.2 Management protocols for the } \\
\text { disposal of lion body parts and } \\
\text { other derivatives (relating to a } \\
\text { phase out of the commercial lion } \\
\text { breeding in RSA) are created and } \\
\text { made publicly available. }\end{array}$ \\
\hline & $\begin{array}{l}\text { 5.3 Conservation value of } \\
\text { commercial lion breeding in } \\
\text { RSA can be overplayed }\end{array}$ & & $\begin{array}{c}5.3 \text { Clear public messaging } \\
\text { guidance (relating to a phase out of } \\
\text { the commercial lion breeding in } \\
\text { RSA) are created and made } \\
\text { publicly available. }\end{array}$ \\
\hline
\end{tabular}

\section{References}

1. Coals, P.; Burnham, D.; Loveridge, A.; Macdonald, D.W.; Sas-Rolfes, M.; Williams, V.L.; Vucetich, J.A. The Ethics of HumanAnimal Relationships and Public Discourse: A Case Study of Lions Bred for Their Bones. Animals 2019, 9, 52. [CrossRef] [PubMed]

2. Hutchinson, A.; Roberts, D.L. Differentiating Captive and Wild African Lion (Panthera leo) Populations in South Africa, Using Stable Carbon and Nitrogen Isotope Analysis. Biodivers. Conserv. 2020, 29, 2255-2273. [CrossRef]

3. Van der Merwe, P.; Saayman, M.; Els, J.; Saayman, A. The Economic Significance of Lion Breeding Operations in the South African Wildlife Industry. Int. J. Biodivers. Conserv. 2017, 9, 314-322.

4. Government Gazette. Biodiversity Action Management Plan for African Lions (Panthera leo). Available online: https://cer.org. $\mathrm{za} /$ wp-content/uploads/2010/05/African-lion.pdf (accessed on 8 June 2021).

5. Harvey, R.G. Towards a Cost-Benefit Analysis of South Africa's Captive Predator Breeding Industry. Glob. Ecol. Conserv. 2020, 23, e01157. [CrossRef]

6. Williams, V.L.; 't Sas-Rolfes, M.J. Born Captive: A Survey of the Lion Breeding, Keeping and Hunting Industries in South Africa PLoS ONE 2019, 14, e0217409. [CrossRef]

7. CITES Trade Database. Available online: https://trade.cites.org/ (accessed on 8 June 2021).

8. Schroeder, R.A. Moving Targets: The 'Canned' Hunting of Captive-Bred Lions in South Africa. Afr. Stud. Rev. 2018, 61, 8-32. [CrossRef]

9. Williams, V.L.; Loveridge, A.J.; Newton, D.J.; Macdonald, D.W. A Roaring Trade? The Legal Trade in Panthera Leo Bones from Africa to East-Southeast Asia. PLoS ONE 2017, 12, e0185996. [CrossRef]

10. Department of Forestry, Fisheries and the Environment. Available online: https://www.environment.gov.za/promotionaccess_ informationact (accessed on 8 June 2021).

11. Hunter, L.T.; White, P.; Henschel, P.; Frank, L.; Burton, C.; Loveridge, A.; Balme, G.; Breitenmoser, C.; Breitenmoser, U. Walking with Lions: Why There Is No Role for Captive-Origin Lions Panthera Leo in Species Restoration. Oryx 2013, 47, 19-24. [CrossRef]

12. Williams, V.L.; Newton, D.J.; Loveridge, A.J.; Macdonald, D.W. Bones of Contention: An Assessment of the South African Trade in African Lion Panthera Leo Bones and Other Body Parts; TRAFFIC: Cambridge, UK; WildCRU: Oxford, UK, 2015.

13. The Revelator. Available online: https:/ / therevelator.org/lion-hunting-south-africa/ (accessed on 8 June 2021).

14. Coals, P.; Moorhouse, T.P.; D'Cruze, N.C.; Macdonald, D.W.; Loveridge, A.J. Preferences for Lion and Tiger Bone Wines amongst the Urban Public in China and Vietnam. J. Nat. Conserv. 2020, 57, 125874. [CrossRef]

15. Biodiversity Act (10/2004). National Environmental Management. Non-Detriment Findings. Available online: https://cer.org. za/wp-content/uploads/2017/12/African-lion.pdf (accessed on 8 June 2021).

16. Bauer, H.; Nowell, K.; Sillero-Zubiri, C.; Macdonald, D.W. Lions in the Modern Arena of CITES. Conserv. Lett. 2018, 11, e12444 [CrossRef]

17. The Conversation. Available online: https://theconversation.com/lion-and-tiger-farming-may-be-inhumane-but-we-dontknow-if-it-increases-poaching-120040 (accessed on 8 June 2021) 
18. Williams, V.L.; Loveridge, A.J.; Newton, D.J.; Macdonald, D.W. Questionnaire Survey of the Pan-African Trade in Lion Body Parts. PLoS ONE 2017, 12, e0187060. [CrossRef]

19. Green, J.; Jakins, C.; Asfaw, E.; Bruschi, N.; Parker, A.; de Waal, L.; D’Cruze, N. African Lions and Zoonotic Diseases: Implications for Commercial Lion Farms in South Africa. Animals 2020, 10, 1692. [CrossRef] [PubMed]

20. Coals, P.; Burnham, D.; Johnson, P.J.; Loveridge, A.; Macdonald, D.W.; Williams, V.L.; Vucetich, J.A. Deep Uncertainty, Public Reason, the Conservation of Biodiversity and the Regulation of Markets for Lion Skeletons. Sustainability 2019, 11, 5085. [CrossRef]

21. The Southern African Legal Information Institute (SAFLII). Available online: http://www.saflii.org/za/cases/ZAGPPHC/2019 /337.html (accessed on 8 June 2021).

22. Department of Forestry, Fisheries and the Environment. Available online: https://www.environment.gov.za/mediarelease/ creecyaapointsadvisorycommittee_managementbreedinghuntingtradehandling_elephantlionleopardrhinoceros (accessed on 8 June 2021).

23. Kim, S.; Ji, Y. Gap Analysis. In The International Encyclopedia of Strategic Communication; Wiley-Blackwell: Hoboken, NJ, USA, 2018; pp. 1-6. ISBN 978-1-119-01072-2.

24. Winch, G.; Usmani, A.; Edkins, A. Towards Total Project Quality: A Gap Analysis Approach. Constr. Manag. Econ. 1998, 16, 193-207. [CrossRef]

25. Lee, Y.-C.; Wang, Y.-C.; Chien, C.-H.; Wu, C.-H.; Lu, S.-C.; Tsai, S.-B.; Dong, W. Applying Revised Gap Analysis Model in Measuring Hotel Service Quality. SpringerPlus 2016, 5, 1191. [CrossRef]

26. Patacsil, F.F.; Tablatin, C.L.S. Exploring the Importance of Soft and Hard Skills as Perceived by IT Internship Students and Industry: A Gap Analysis. J. Technol. Sci. Educ. 2017, 7, 347-368. [CrossRef]

27. Tsai, W.-H.; Hsu, W.; Chou, W.-C. A Gap Analysis Model for Improving Airport Service Quality. Total Qual. Manag. Bus. Excell. 2011, 22, 1025-1040. [CrossRef]

28. Maxted, N.; Dulloo, E.; Ford-Lloyd, B.V.; Iriondo, J.M.; Jarvis, A. Gap Analysis: A Tool for Complementary Genetic Conservation Assessment. Divers. Distrib. 2008, 14, 1018-1030. [CrossRef]

29. Department of Forestry, Fisheries and the Environment. Available online: https://www.environment.gov.za/sites/default/files/ reports/2020-12-22_high-levelpanel_report.pdf (accessed on 8 June 2021).

30. NSPCA. Overview of Inspection to Lion Breeding Farms by the National Wildlife Protection Unit Inspectorate during the Period March 2016-June 2017; National Society for Prevention of Cruelty to Animals (NSPCA): Alberton, South Africa, 2017.

31. Pijoos, I. 'Bottle-Fed or Not, Lions Remain Dangerous': Warning after Lodge Owner's Death, as Family Mourns. The Sunday Times. 28 August 2020. Available online: https:/ /www.timeslive.co.za/news/south-africa/2020-08-28-bottle-fed-or-not-lionsremain-dangerous-warning-after-lodge-owners-death-as-family-mourns/ (accessed on 12 May 2021).

32. Froneman, A. Escaped Limpopo Lions Found. Getaway. 13 May 2020. Available online: https://www.getaway.co.za/travelnews/escaped-limpopo-lions-found/ (accessed on 12 May 2021).

33. Wilson, A. Animal Law in South Africa: "Until the Lions Have Their Own Lawyers, the Law Will Continue to Protect the Hunter; dA.Derecho Animal (Forum of Animal Law Studies): Barcelona, Spain, 2019.

34. SATSA. A Guide and Tool by SATSA the Southern Africa Tourism Services Association: Evaluating Captive Wildlife Attractions E Activities; South African Tourism Association: Johannesburg, South Africa, 2019.

35. Everatt, K.T.; Kokes, R.; Pereira, C.L. Evidence of a Further Emerging Threat to Lion Conservation; Targeted Poaching for Body Parts. Biodivers. Conserv. 2019, 28, 4099-4114. [CrossRef]

36. Nowell, K. Tiger farms and pharmacies: The central importance of China's trade policy for tiger conservation. In Tigers of the World; Elsevier: Amsterdam, The Netherlands, 2010; pp. 463-475.

37. Lindsey, P.; Alexander, R.; Balme, G.; Midlane, N.; Craig, J. Possible Relationships between the South African Captive-Bred Lion Hunting Industry and the Hunting and Conservation of Lions Elsewhere in Africa. S. Afr. J. Wildl. Res. 2012, 42, 11-22. [CrossRef]

38. Hinsley, A.; 't Sas-Rolfes, M. Wild Assumptions? Questioning Simplistic Narratives about Consumer Preferences for Wildlife Products. People Nat. 2020. [CrossRef]

39. Hübschle, A. Fluid Interfaces between Flows of Rhino Horn. Glob. Crime 2017, 18, 198-217. [CrossRef]

40. Safari Club International Anti-Hunting Propaganda Ignores Reality. 22 March 2019. Available online: https://safariclub.org/ anti-hunting-propaganda-ignores-reality/ (accessed on 12 May 2021).

41. Newsome, D. The Collapse of Tourism and Its Impact on Wildlife Tourism Destinations. J. Tour. Futures 2020. [CrossRef]

42. BBC. Coronavirus: Vietnam Bans Wildlife Trade over Pandemic Risk. 24 June 2020. Available online: https://www.bbc.co.uk/ news / world-asia-53525954 (accessed on 12 May 2021).

43. Wilson, S.M.; Bradley, E.H.; Neudecker, G.A. Learning to Live with Wolves: Community-Based Conservation in the Blackfoot Valley of Montana. Hum. Wildl. Interact. 2017, 11, 4.

44. König, H.J.; Ceaușu, S.; Reed, M.; Kendall, H.; Hemminger, K.; Reinke, H.; Ostermann-Miyashita, E.-F.; Wenz, E.; Eufemia, L.; Hermanns, T. Integrated Framework for Stakeholder Participation: Methods and Tools for Identifying and Addressing Human-Wildlife Conflicts. Conserv. Sci. Pract. 2021, 3, e399.

45. Can, Ö.E.; D'Cruze, N.; Garshelis, D.L.; Beecham, J.; Macdonald, D.W. Resolving Human-Bear Conflict: A Global Survey of Countries, Experts, and Key Factors. Conserv. Lett. 2014, 7, 501-513. [CrossRef]

46. Burgess, G. Powers of Persuasion. Traffic Bull. 2016, 28, 65. 
47. Tensen, L. Under What Circumstances Can Wildlife Farming Benefit Species Conservation? Glob. Ecol. Conserv. 2016, 6, 286-298. [CrossRef]

48. Harfoot, M.; Glaser, S.A.M.; Tittensor, D.P.; Britten, G.L.; McLardy, C.; Malsch, K.; Burgess, N.D. Unveiling the Patterns and Trends in 40 years of Global Trade in CITES-Listed Wildlife. Biol. Conserv. 2018, 223, 47-57. [CrossRef]

49. Baker, S.E.; Cain, R.; Van Kesteren, F.; Zommers, Z.A.; D'cruze, N.; Macdonald, D.W. Rough Trade: Animal Welfare in the Global Wildlife Trade. BioScience 2013, 63, 928-938.

50. Green, J.; Coulthard, E.; Norrey, J.; Megson, D.; D'Cruze, N. Risky Business: Live Non-CITES Wildlife UK Imports and the Potential for Infectious Diseases. Animals 2020, 10, 1632. [CrossRef] [PubMed]

51. Glover, M. Britain Bans Fur Farms. Anim. Agenda 2001, 21, 14.

52. D'Cruze, N.; Alcock, R.; Donnelly, M. The Cayman Turtle Farm: Why We Can't Have Our Green Turtle and Eat It Too. J. Agric. Environ. Ethics 2015, 28, 57-66. [CrossRef]

53. World Animal Protection. Available online: https://www.worldanimalprotection.org/sites/default/files/media/int_files/bear_ bile_white_paper.pdf (accessed on 8 June 2021).

54. Crudge, B.; Nguyen, T.; Cao, T.T. The Challenges and Conservation Implications of Bear Bile Farming in Viet Nam. Oryx 2018, 54, 252-259. [CrossRef]

55. Standaert, M. Coronavirus Closures Reveal Vast Scale of China's Secretive Wildlife Farm Industry. The Guardian. 25 February 2020. Available online: https:/ / www.theguardian.com/environment/2020/feb/25/coronavirus-closures-reveal-vast-scale-ofchinas-secretive-wildlife-farm-industry (accessed on 12 May 2021). 